\title{
Effect of Ethephon (2-chloroethyl phosphonic acid) on Vascular Cambial Strength of Almond Tree Trunks
}

\author{
Sunitha H. Gurusinghe and Kenneth A. Shackel ${ }^{1}$ \\ Department of Pomology, University of California, Davis, CA95616 \\ Additional index words. shaker harvesting, shaker damage, ray initial and fusiform initial ratio. Ceratocystis fimbriata
}

\begin{abstract}
Mechanized shaker harvesting of large acreages of almond [Prunus dulcis (Mill.) Webb.] trees leads to economical use of labor, general cost reduction, and speed of harvest. However, shaking can separate the bark (all tissues external to the vascular cambium) from the wood (all tissues internal to the vascular cambium) and exposes the vascular cambial zone to infection by the fungus Ceratocystis fimbriata Ell. \& Halst. leading to mallet wound canker and loss of productivity. Treatment of ethephon caused a significant increase in the cambial strength of both branches and trunks, presumably by ethylene-induced anatomical and biochemical changes in the cambial zone. An increase in the ratio of total tangential area of the groups of ray initials to fusiform initials and the thickness of ray initial cell walls was observed as a response to ethephon treatment. Spraying an ethephon solution $\left(500 \mu \mathrm{l}-\right.$ liter $\left.^{-1}\right)$ to the runoff point on almond trunks caused significant increases in the cambial strength; ethephon, therefore, may be useful in reducing bark injury during shaker harvesting.
\end{abstract}

Mechanized harvesting by tree shakers is necessary for economic almond production in California. However, shaking can separate the bark (all tissues external to the vascular cambium) from the wood (all tissues internal to the vascular cambium) when the maximum shear forces generated in the vascular cambial zone and the bark are insufficient to resist the shear forces externally applied to the bark surface by the shaker (Diener et al., 1968; Fridley et al., 1970). During debarking (studies related to pulp and paper), Fiscus et al. ( 1983) and Einsphar et al. ( 1984) consistently observed fracture in the cambial zone proper (cambial initials and xylem and phloem mother cells) in the month of May, shifting to the zone of differentiating secondary xylem in June and then back toward the zone of differentiating phloem in August. Therefore, fracture during shaking is highly possible through any undifferentiated cells or differentiating cells: hence, in this study, the definition of cambial zone includes the cambial zone proper and all cells undergoing differentiation. For an isolated section of bark on the trunk, the maximum shear stress at cambial failure is called tangential (or longitudinal) cambial strength, depending on the direction of shear (Fridley et al., 1970). Injury to the cambial zone allows infection by the fungus Ceratocystis fimbriata, which results in low productivity and premature death of almond trees (De Vay et al., 1960. 1968). Therefore, it is important to determine whether the cambial strength can be increased by cultural or other practices.

Ethylene is known to cause numerous biochemical changes in the composition of the cell wall materials, and many of these changes could contribute to cell wall strength. It has been postulated, for instance, that chemical cross-linkages (McCann et al., 1990) control the extensibility of cell walls during growth and development (Fry, 1988). Ridge and Osborne ( 1970) reported that, in etiolated pea seedlings, exposure to ethylene caused increases in peroxide activity and the hydroxyproline content of cell walls.

Received for Publication 18 Feb. 1994. Accepted for publication 4 Aug. 1994. This work supported in part by a grant from the California Almond Board. Usc of trade names does not imply endorsement of the products named nor criticism of similar ones not named. The cost of publishing this paper was defrayed in part by the payment of page charges. Under postal regulations, this paper therefore must be hereby marked advertisement solely to indicate this fact.

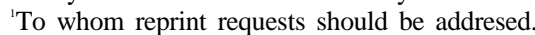

Ethylene also induced changes in the localization of a class of cell wall hydroxyproline-rich glycoproteins called extensins from secondary xylem to stem epidermal and cortical cells. The crosslinked extensin matrix is rigid, inextensible, and resistant to extraction or degradation. Ethylene enhances the biosynthesis of phenolic acids, which are precursors of lignin (Rhodes and Wooltorton, 1973; Shain and Hillis, 1973). Within the xylem differentiating zone, adjacent to the cambial zone proper (Esau, 1965; Philipson and Ward, 1965; Wilson et al., 1966), the middle lamella is known to form a low molecular weight p-hydroxyphenyl lignin (Eom et al., 1987; Fukushima and Terashima, 1990), which potentially could be increased with an ethephon treatment. The presence of lignin in the middle lamella of the differentiating and enlarging secondary xylem cell walls could result in an increase in strength of the cambial zone.

Ethephon, which decomposes into gaseous ethylene, chloride, and phosphate ions (Maynard and Swan, 1963) is known to cause changes in vascular anatomy. Many workers have found that ethephon increases xylem wall thickness and reduces the diameter of vessel elements and trachieds (Barker, 1979; Phelps et al., 1980; Robnett and Morey, 1974; Yamamoto and Kozlowski, 1987a, Yamamoto et al., 1987). Yamamoto et al., (1987) and Yamamoto and Kozlowski (1987a) observed an increased number of ray cells and rays in the mature secondary xylem of Ulmus americana and Pinus halapensis seedlings due to ethephon application. Although these changes were observed in the mature secondary xylem, vessels would begin to enlarge in the xylem differentiating zone, which is also liable to shear failure just as the cambial zone proper (Einsphar et al., 1984; Fiscus et al., 1983). Hence, a reduction in mature vessel and trachied diameters suggests that the process of cell enlargement in the secondary xylem differentiating zone has been suppressed by ethephon and, therefore, may give an increase in the amount of cell wall material per unit area in this zone. If this secondary xylem differentiating zone is compared with a secondary xylem differentiating zone where cell wall enlargement is not suppressed, less force may be needed to fracture through an enlarging or just enlarged cell layer than in a similar zone with cells of a lesser diameter.

In a study by Gurusinghe and Shackel (1995) it was shown that increased cambial strength during the growing season was not 
associated with increased tree water stress or a reduced trunk growth rate. Hence, in the present study, ethephon has been tested on trunks and branches of almond trees as a possible treatment to increase cambial strength. Ethephon-induced biochemical and anatomical changes could increase the strength and the amount of cell wall material in the sheared area of the cambial zone and hence could increase cambial strength.

\section{Materials and Methods}

Research was conducted at the Univ. of California, Davis (UCD), Pomology Experimental Orchards during Spring, Summer, and Fall 1989-92 and in the Univ. of California West-Side Research and Experimental Center, Five Points, Calif., in Summer 1992. 'Nonpareil', 'Mission', and 'Carmel' almond trees were used in the study.

Measurement of vascular cambial strength and cambial growth. The methods used to measure trunk and branch cambial strength have been described by Gurusinghe and Shackel (1995). In both cases the shearing force $(\mathrm{F})$ required to separate wood from a section of bark with an area (A) was measured and expressed as F/ A, or cambial strength $(\mathrm{kPa})$. Daily radial growth measurements $\left(\mathrm{mm} \cdot \mathrm{day}^{-1}\right)$ on the trunk of a single ethephon-treated tree and a control tree were made using resistive position transducers (Spring Return Linear Sensor Module Resistor, Duncan Electronics, Costa Mesa, Calif.) mounted to the trunk and connected to a CR10 datalogger (Campbell Scientific, Logan, Utah) as described in Gurusinghe and Shackel (1995).

Cambial anatomy. Two-year-old branches (14 to $20 \mathrm{~mm}$ in diameter) were cut into discs 4 to $5 \mathrm{~mm}$ thick with a small, circular, precision power saw before sectioning or preserving in FAA (4\% formalin : 50\% acetic acid : 70\% ethyl alcohol). Tangential sections and $10-\mu \mathrm{m}$ cross-sections were from discs of fresh or preserved material mounted on a sliding microtome; glycerine $(100 \%)$ was added continually to the cutting surface to prevent folding and dehydration of the sections on the knife. The tangential sections were sequentially cut and immediately dipped in saturated solution of phloroglucinol in $20 \% \mathrm{HCl}$ for $\approx 20 \mathrm{sec}$. A red-violet color was produced in the middle lamella and the entire secondary xylem cell walls by phloroglucinol when the sections reached the secondary xylem. This marked change in the depth of wall coloration observed along with the sequential cutting of tangential sections was used as a guide to identify the limits of the cambial zone. Within the recently formed cambial differentiating zone there was occasionally a very light-pink stain occurred exclusively in the middle lamella but no coloration was present in the primary or secondary cell walls.

For mature ( $>8$ years old) trunk samples, the rough outer bark was removed by scraping with a file and $\mathrm{a} \approx 1-\mathrm{cm}^{2}$ section of inner bark with attached cambial tissues was removed with a knife. The cambial zone was sectioned tangentially as described previously for the branches.

For branches and trunks, the area of the tangential view of the groups of fusiform initials (future secondary xylem) and the groups of ray initials (future rays) and the thickness of the cambial zone in cross-sections were outlined using a camera lucida. The ratio of the total tangential areas occupied by the groups of ray initials and groups of fusiform initials in the tangential view were calculated using a computerized graphic data digitizer (NIH Image 1.41; Symantec Corp.). All comparisons were made between pairs of control and ethephon-treated samples obtained on a given date and identically prepared.

Ethephon treatments. In Davis, 2-year-old almond branches on mature trees were infused with an ethephon solution of 250 $\mu \mathrm{l} \cdot \mathrm{liter}^{-1}$ in Spring 1990 and $500 \mu \mathrm{l} \cdot \mathrm{liter}^{-1}$ in Spring 1991. About $500 \mathrm{ml}$ of ethephon solution was infused (0.25 liters.day $\left.{ }^{-1}\right)$ through a cotton wick wrapped around a half-girdled branch and covered with aluminum foil. Medical intravenous bags were used as reservoirs to hold the solution and keep the cotton wick constantly wet. Controls were similarly infused with water. Tree trunks were sprayed (cylindrical spray area in the trunk covered only the region subjected to shaker clamping) to the point of runoff, once with a $500 \mu \mathrm{l} \cdot$ liter $^{-1}$ ethephon solution (in Davis, 28 May 1992) and twice with $300 \mu 1 \cdot$ liter $^{-1}$ (in West-Side Research and Experimental Center, 4 Apr. and 15 July 1992) using a manually operated sprayer. In the West-Side field station. a total of 32 ethephontreated $\left(300 \mu \mathrm{l} \cdot \mathrm{liter}^{-1}\right)$ and control tree trunks (eight ethephontreated and eight control trunks in each of 'Carmel' and 'Nonpareil'), -20 years old, were assigned treatments as a complete randomized design $(2 \times 2$ factorial $)$.

\section{Results}

Branches infused with ethephon (either 250 or $500 \mu \mathrm{l} \cdot \mathrm{liter}^{-1}$ ) showed a large increase in cambial strength. A total of 18 paired comparisons of almond branches (Nonpareil and 'Mission') infused with ethephon in 1990-91 showed a mean \pm SD cambial strength of $840 \pm 100 \mathrm{kPa}$, whereas controls had a mean \pm SD of 590 $\pm 90 \mathrm{kPa}$. There were no statistically significant differences between the two varieties, with or without ethephon treatment. A $t$ test comparison showed highly significant treatment differences $(P \leq 0.0001)$. The effect of ethephon on cambial strength was localized around the point of treatment, with the highest cambial strength near the point of ethephon infusion $(25 \mathrm{~cm}$ from the point of infusion) and a progressive decline in cambial strength, to the

900

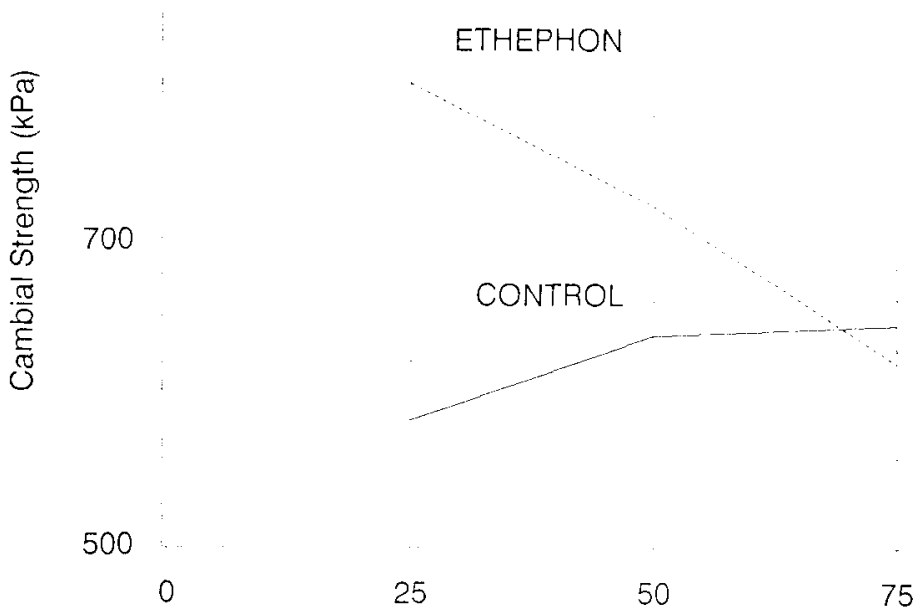

Distance from Point of Infusion to Branch Tip

(cm)

Fig. 1. Branch cambial strength at an increasing distance from the point of ethephon infusion $\left(250 \mathrm{ul} \cdot \mathrm{liter}^{\prime}\right)$ or water infusion in the almond cultivar "Nonparcil". Thirty discs were measured on each of three replicate branches. Vertical bars correspond to the mean \pm 2 SE of the three branch replicates. 


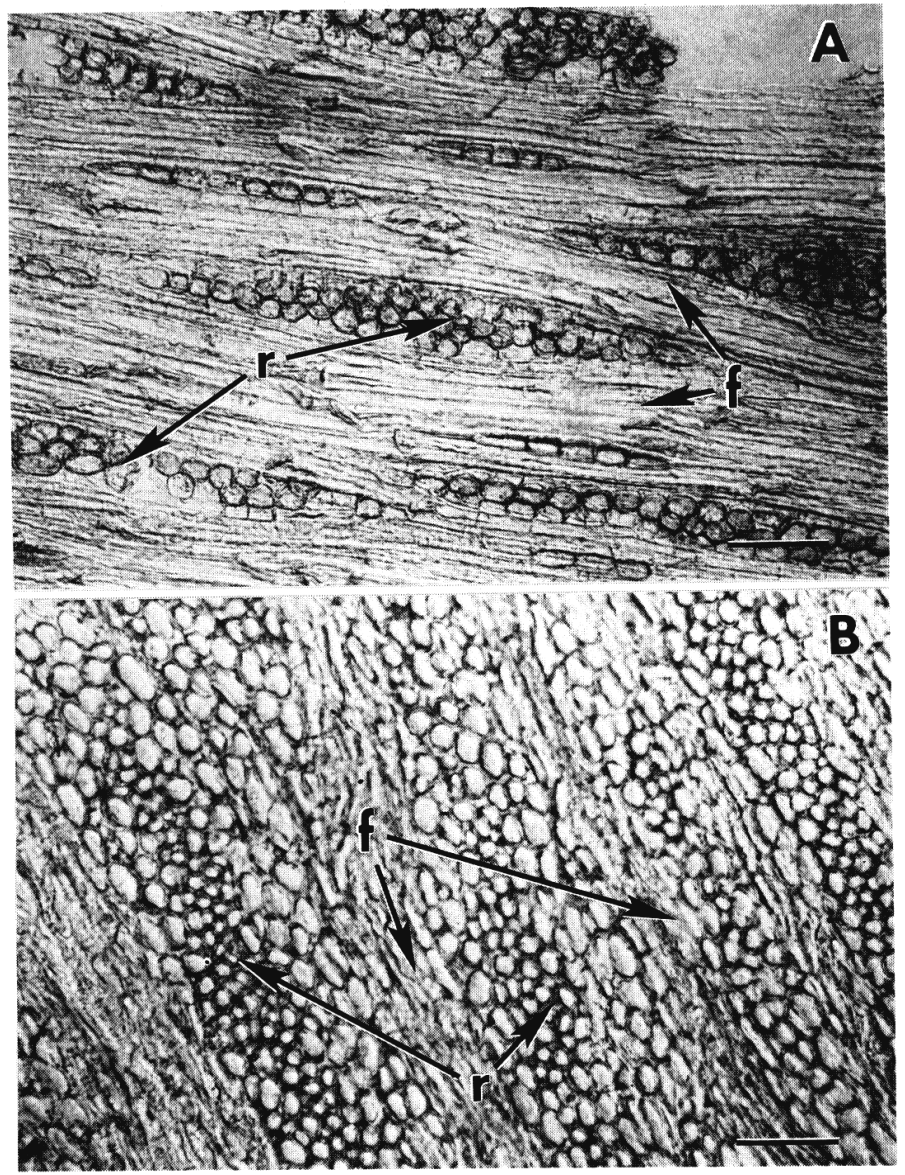

Fig. 2. Tangential sections of the cambial zone in (A) control branches and (B) ethephon-infused branches of almond cultivar 'Nonpareil', showing differences in the areas occupied by the initials of ray (r) and fusiform (f) cells. Note the apparent increase in cell wall thickness in the ray initials of the ethephon-treated sample compared to the control. Scale bar $=50 \mu \mathrm{m}$.

level of the control, at more distal points (Fig. 1). In control branches, the lowest cambial strength was at the point of water infusion, with an increasing trend towards the tip of the branch.

Ethephon also caused a number of anatomical changes in branches. The proportion of tangential area occupied by ray initials was much higher in treated as compared to control branches (Fig. $2 \mathrm{~A}$ and $\mathrm{B})$. For these branches treated with ethephon, this increased proportion of ray compared to fusiform tangential area (i.e., ray to fusiform area ratio) remained even in the following year, with an identical appearance of tangential cross sections to that shown in Fig. 2B, when samples were taken between 12 to 15 months following a single ethephon infusion. The ethephontreated branches also had a significantly larger diameter than the control branches (mean \pm SD of $44.2 \pm 5.7 \mathrm{~mm}$ in treated branches and mean \pm SD of $29.9 \pm 2.7 \mathrm{~mm}$ in control branches) after 12 to 15 months, indicating a higher growth rate in the ethephon-treated branches compared to the control branches. In trunks, the change in ray to fusiform area ratio due to ethephon treatment was slight (Fig. $3 \mathrm{~A}$ and B) compared to that which occurred in the branches. It is also clear that the ray-to-fusiform area ratio in the control trunks is substantially greater than in the control branches, suggesting that an increase in this ratio is a normal feature of stem maturation. The ethephon-treated branches also appeared to have thicker cell walls in the ray initials than the controls (Fig. 2 A and B). Thicker walls in the group of ray initials were also suggested

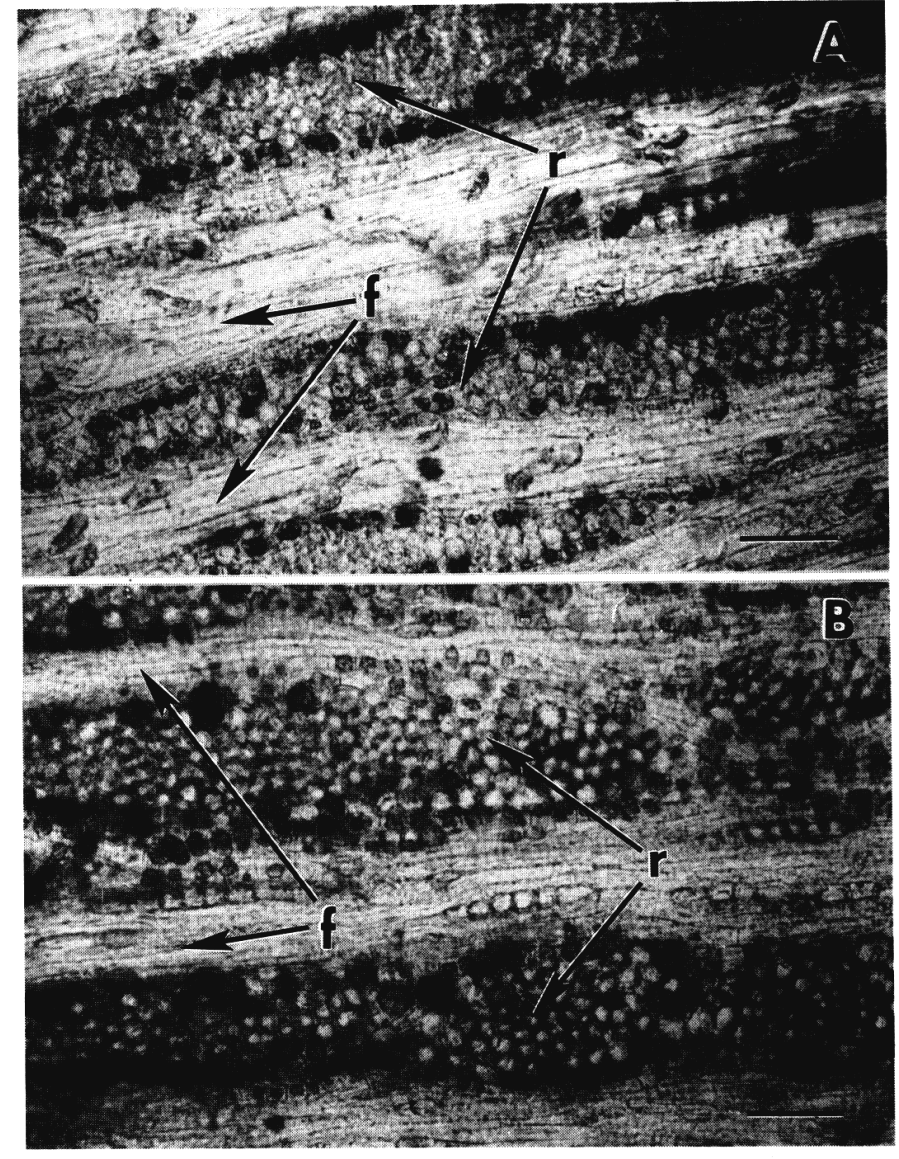

Fig. 3. Tangential sections of the cambial zone in (A) control trunks and (B) ethephon sprayed trunks of almond cultivar, 'Nonpareil' showing ray (r) and fusiform (f) initials as in Fig. 2. Scale bar $=50 \mu \mathrm{m}$.

in trunks (Fig. 3A), but electron microscopy or improved staining techniques are needed to provide more definitive evidence.

A seasonal increase in cambial strength occurred in ethephontreated and control branches (Fig. 4). The change in the ray-tofusiform area ratio was not apparent until 5 months after ethephon feeding, whereas the increase in cambial strength due to ethephon treatment occurred within 2 weeks (Fig. 4). In 1992, branches were sprayed with high ethephon concentrations (1000 to $2000 \mu \mathrm{l} \cdot$ liter $^{-1}$ ) and a reduction or no change in cambial strength was found. Also, no change in the ray-to-fusiform area ratio was observed.

Cambial strength increased in trunks of 'Nonpareil' trees sprayed with $500 \mu \mathrm{l} \cdot$ liter $^{-1}$ ethephon (Fig. 5b), with significant differences observed within 2 weeks after spraying. The high cambial strength in midwinter (February) declined in the control trees by June, whereas it increased in ethephon-treated trees. Short-term (1 to 2 days) fluctuations in cambial strength occurred, as have been observed by the other workers (Brown et al., 1987; Fridley et al., 1970), but the fluctuations in cambial strength were in the same direction in treated and control trees (Fig. 5b). The differences in cambial strength due to ethephon treatment disappeared after a few months. Consistent with the growth increase caused by ethephon in branches, there was a substantial increase in ethephon-treated trunk growth rate (Fig. 5a), indicating that cambial strength was not negatively affected by high cambial activity per se.

At the West-Side Research and Experimental Center there were significant increases in cambial strength in the ethephon-treated trees compared to the control trees (Table 1), but no significant 


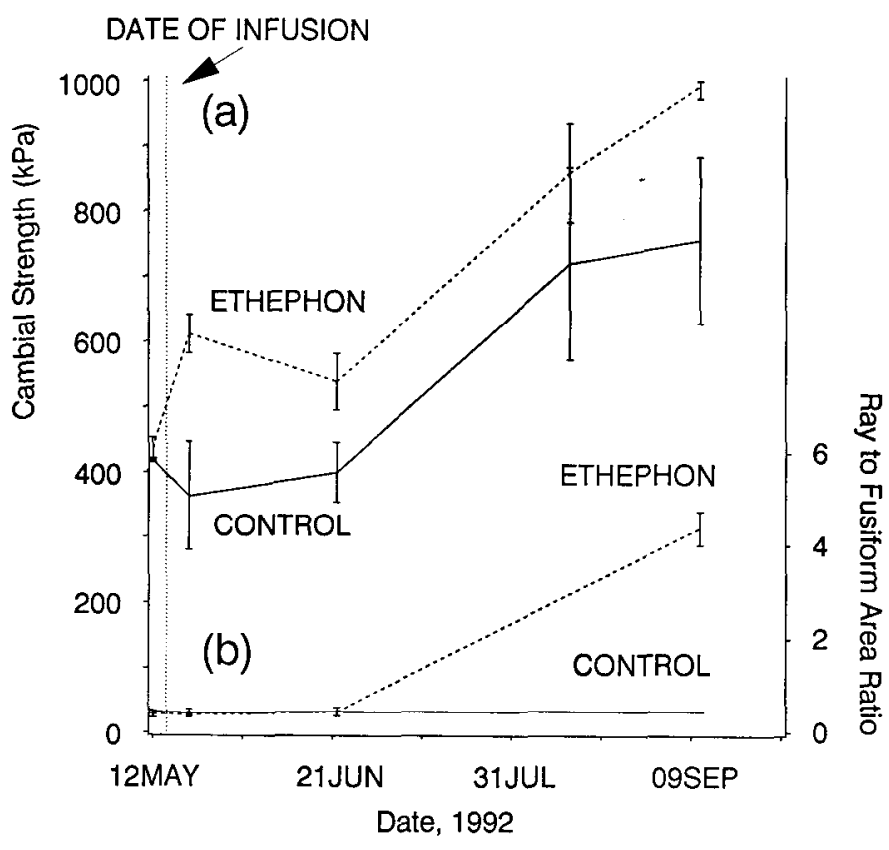

Fig. 4. Cambial strength and the ray to fusiform area ratio of ethephon-treated (250 $\mu \mathrm{l} \cdot$ liter $^{-1}$ ) and control almond branches in the cultivar 'Nonpareil'. (a) Ten discs were measured on each of two replicate branches. Vertical bars correspond to \pm 2 SE of the two-branch replicate. (b) Measurements of two tangential sections were made for each branch with vertical bars as in a.

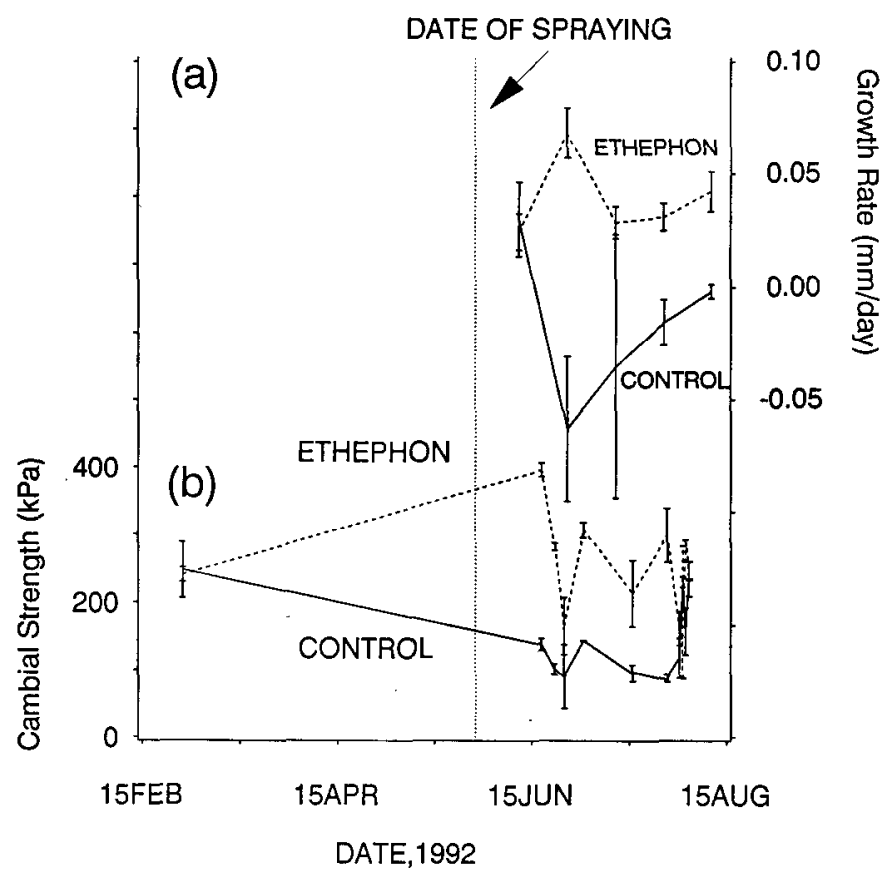

Fig. 5. Cambial strength and radial growth of ethephon-treated $\left(500 \mu \mathrm{l} \cdot\right.$ liter $\left.^{-1}\right)$ and control almond trunks of cultivar 'Nonpareil'. (a) Measurements on a single control and ethephon treated trunk were made daily and biweekly mean \pm 2 SE are shown. (b) Measurements were taken 2 days randomly from each of 2 control and 2 ethephon treated trunks every week with a single measurement on each day. Each bar represents the biweekly mean \pm 2 SE for a single tree.

difference was found between 'Carmel' and 'Nonpareil'. The mean $(207 \mathrm{kPa})$ of cambial strength of control trees ranged from 103 to $310 \mathrm{kPa}$, whereas the mean $(275 \mathrm{kPa})$ of the treated trunks ranged from 172 to $517 \mathrm{kPa}$.
Table 1. Analysis of variance (type III sum of squares) for eight ethephontreated tree trunks (300 $\left.\mu \mathrm{l} \cdot \mathrm{liter}^{-1}\right)$ and eight control trees in each of the variety ('Carmel' and 'Nonpareil') with a complete randomized plot design $(2 \times 2$ factorial $)$. Varietal differences were not significant.

\begin{tabular}{lcccc}
\hline \hline $\begin{array}{l}\text { Source of } \\
\text { variation }\end{array}$ & $\mathrm{df}$ & $\begin{array}{c}\text { Mean } \\
\text { square }\end{array}$ & $\begin{array}{c}\mathrm{F} \\
\text { value }\end{array}$ & $P>\mathrm{F}$ \\
\hline Ethephon (E) & 1 & 35516 & 6.32 & 0.018 \\
Variety (V) & 1 & 2283 & 0.41 & 0.529 \\
E $\times$ V & 1 & 1614 & 0.29 & 0.596 \\
Residual & 28 & 5616 & & \\
\hline
\end{tabular}

${ }^{2}$ Degrees of freedom

\section{Discussion}

The increase in cambial strength that was observed in ethephontreated branches clearly preceded any detectable change in the rayto-fusiform area ratio (Fig. 4) and, hence, may have been due to ethylene-induced biochemical changes in the cell walls. The cell wall biochemical changes reported to be associated with ethephon treatment (Eom et a1., 1987; Fukushima and Terashima, 1990) usually increase the number of-covalent and noncovalent crosslinks in the cell walls. Highly condensed guaiacyl type lignin, rich in phenolic hydroxyl groups, was found to be deposited exclusively in the middle lamella at a very early stage of xylem differentiation in a number of hardwood species (Eom et al., 1987; Fukushima and Terashima, 1990). This is a stage of differentiation within our definition of the cambial zone. Rhodes and Wooltorton (1973) and Shain and Hillis (1973) have observed an increase in lignin precursor concentrations due to ethephon application. Therefore, it is reasonable to expect these lignin depositions in the middle lamella of the differentiating xylem to be increased with ethephon application. An ethephon-induced increase in the concentration of extensin (Cassab et al., 1988; Ridge and Osborne, 1970) and pectin polymers (Weinbaum et al., 1979) also could contribute to strengthening the cell walls. Extensin expression has been correlated with the ability of cells to resist lysis in hypotonic medium, with the inhibition of cell elongation during normal development and an increase in resistance to attack by virulent pathogens (Fry 1982; 1986; 1988; Lamport and Northcote, 1960). Ethylene-treated prune fruit mesocarp cells were found to be more difficult to separate by enzyme-mediated isolation procedures than the mesocarp cells of untreated fruit (Weinbaum et al. 1979). In the same study, an increase in the proportion of pectic polymers in the mesocarp cell walls of treated fruit was observed. Carboxyl groups of unesterified pectic polymers can produce cross-links with $\mathrm{Ca}^{2+}$ and strengthen the cell plates and primary walls (Fry 1988).

Yamamoto and Kozlowski (1987a, 1987b) observed an increase in the number of ray cells and the number of rays in the mature xylem due to ethephon application. Normally, the majority of cells in the cambial zone proper are fusiform initials, which have their long axes parallel to the long axis of the trunk, whereas the long axes of the ray initials run radially (Esau, 1965). The mechanical strength of wood is highest in the direction of the axis of the majority of its cells (Schniewind et al., 1989), and this is attributed to the fact that the predominant orientation of the cellulose microfibrils is parallel to the cell long axis and hence parallel to the direction of testing of strength (Dinwoodie, 1981). The predominant orientation of cellulose microfibrils in primary walls is also believed to be parallel to the long axis following cell elongation (Salisbury and Ross, 1985), and consistent with this belief was our finding (Gurusinghe and Shackel, 1995) that longitudinal cambial strength was higher than tangential cambial strength. Hence, we 
would expect an increase in the proportion of ray initials (Fig. 2B and Fig. 3B), whose long axis is perpendicular to the test axis, to be associated with a decrease in the longitudinal shear strength of the cambium rather than an increase, as was observed in this study. Many workers however, have found that ethephon increases primary and secondary wall thickness in xylem and trachieds, and reduces the diameter of vessels and trachieds (Barker, 1979; Phelps et al., 1980; Robnett and Morey, 1974; Yamamoto et al., 1987; Yamamoto and Kozlowski 1987a) and it is possible that there was an increase in the cambial wall thickness in our ethephon treated samples (Fig. 2B and Fig. 3B). Together with the possible biochemical changes mentioned above, an increase in the wall thickness may be compensating for the expected reduction in strength, based on the proportional increase in ray initials.

The fact that an increased growth rate (Fig. 5a) did not necessarily lead to reduced cambial strength (Fig. 5b) further supports the hypothesis (Gurusinghe and Shackel, 1995), that changes in cambial strength are not directly related to changes in cambial growth, as is often assumed (Fridley et al., 1970; Brown et al., 1987). Many other workers have observed increased vascular cambial activity (increased phloem and xylem production) following ethephon treatment (Barker, 1979; Brown and Leopold, 1973; Nelson and Hillis, 1978; Phelps et al., 1980; Robnett and Morey, 1974) similar to our observations of the increasced diameter of ethephon treated branches compared to control branches and the increased growth rate in the treated tree trunk compared to the control (Fig. 5).

It is possible that higher doses of ethephon than those used in our study might further increase cambial strength. However, ethephon dosages required for obtaining a maximum cambial strength must be balanced against doses causing undesirable responses such as abnormal and high resin gum secretion and gum duct formation, which have been found in almonds (Morrison et al., 1987a, 1987b). The doses used in our study did not cause any apparent adverse effects on flowering, fruit set, fruit yield, or leaf abscission following the branch infusion or spraying on the trunk.

\section{Conclusions}

Ethephon treatment caused a significant and relatively long lasting increase in the cambial strength of both almond branches and trunks, possibly by compositional changes in cell walls. Thus, ethephon may be useful in reducing bark injury during shaker harvesting.

\section{Literature Cited}

Barker, J.E. 1979. Growth and wood properties of Pinus radiata in relation to applied ethylene. N.Z. J. For. Sci. 9:15-19.

Brown, G.K., J.R. Frahm. L.J. Segerlind, and B.F. Cargill. 1987. Bark strengths and shaker pads vs. cherry bark damage during harvesting. Trans. Amer. Soc. Agr. Eng. 30(5):1266-1271.

Brown, K.M. and A.C. Leopold. 1973. Ethylene and the regulation of growth in pine. Can. J. For. Res. 3:143-145.

Cassab, G.I., J. Lin, L. Lin, and J.A. Varner. 1988. Ethylene effect on extensin and peroxidase distribution in the subapical region of pea epicotyls. Plant Physiol. 88:522-524

De Vay, J.E., H. English. F.L. Lukezic, and H.J. O'Reilly. 1960. Mallet wound canker of almond trees. California Agr. 14(8):8-9.

De Vay, J.E., F.L. Lukezic, H. English, E.E. Trujillo, and W.J. Moller. 1968 Ceratocystis canker of deciduous fruit trees. Phytopathology 58:949-54.

Diener, R.G., F.H. Buelow, and G.E. Masc. 1968. Viscoclastic analysis of the behavior and properties of cherry bark and wood under static and dynamic loading. Trans. Amer. Soc. Agr. Eng. 11(3):323-330.
Dinwoodie, J.M. 1981. Timber: Its Nature and Behaviour. Van Nostrand. Co.. New York.

Einsphar, D.W., R.H. Van Epren, and M.L. (Harder) Fiscus. 1984. Morphological and hark strengh characteristics important to wood/bark adhesion in hardwood। Wood Fiber Sci. Tech. 16(3):339-348.

Eom, T.J., G. Meshitslika, and J. Nakano. 1987. Structural characteristics of compound middle lamella lignin. IV. Intl. Symp. on Wood and Pulping Chemistry. ISWPC (2):27-30.

Esau, K. 1965. Plant anatomy. 2nd ed. Wiley, New York.

Fiscus. M., R.H. Van Eperen, and D.W. Einsphar. 1983. Method for obtaining wood/bark adhesion measurements on small samples. Wood Fiber Sci. 15(3):219 222.

Fridley. R.B., G.K. Brown. and P.A. Adrian. 1970. Strength characteristic of fruit tree bark. Hilgardla 40(8):205-222.

Fry, S.C. 1982. Ibodityrosine, a new cross-linking 7 amino acid from plant cell wall glycoprotein. Biochem. J. 204:449-455.

Fry, S.C. 1986. Cross-linking of matrix polymers in the growing cell walls of angiosperms. Annu. Rev. Plant Physiol. 37:165-86.

Fry. S.C. 1988. The growing plant cell wall: Chemical and metabolic analysis. Wiley, New York.

Fukushima, K. and N. Terashima. 1990. Heterogeneity in formation of lignin. XIII. Formation of p-hydroxyphenyl lignin in various hardwoods visualized by microautoradiography. J. Wood Tech. 10(4):413-433.

Gurusinghe,S.H.and K.A .Shackel. 1995. The relation of cumbial zone mechanical strength to growth and irrigation of almond trees [Prunus dulcis (Mill.) Webb.] J. Amer. Soc. Hort. Sci. 120:170-176.

Lamport. D.T.A. and D.H. Northcote. 1960. Hydroxyproline in the cell walls of higher plants. Nature 188:665-666.

Maynard. J.A. and J.M. Swan. 1963. Organophosphorus compounds. i)chloroethyl phosphonic acids as phosphorylating agents. Austral. J. Chem. 16:596-608.

McCann, M.C.. B. Wells. and K. Roberts. 1990. Direct visualization of cross-links in the primary plant cell wall. J. Cell Sci. 96:323-334.

Morrison, J.C.. J.M. Lahavitch. and L.C. Greve. 1987a. The role of ethylene in initiating gum duct formation in almond fruit. J. Amer. Soc. Hort. Sci.112:364 367

Morrison, J.C., L.C. Greve, and J.M. Lahavitch. 1987b. The role of cell walldegrading enzymes in the formation of gum ducts in almond fruits. J. Amer.Soc. Hort. Sci. 112:367-372.

Nelson. N.D. and W.E. Hillis. 1978. Ethylene tension wood formation in Eucalyptus gonocepala. Wood Sci. Technol.12:300-315

Phelps, J.E., E.A. McGinnes, Jr., M. Saniews. J. Pienialek, and M. Smolinaki. 1980. Some anatomical observations on the effect of morphactin IT 3456 and ethrel on wood formation in Salix fragilis L. IAWA Bul. n.s. 1:76-82.

Philipson, W.R. and J.M. Ward. 1965. The ontogeny of the vascular cambium in the stem of seed plants. Bio. Rev. 40:534-579.

Rhodes. M.J.C. and L.S.C. Wooltorton. 1973. Stimulation of phenol acid and lignin biosynthesis in swede root tissue by ethylene. Phytochemistry 12:107-118.

Ridge, I. and D.J. Osborne. 1970. Hydroxyproline and peroxidase in cell walls of Pisum sativum: regulation by ethylene. J. Expt. Bot. 21:843-856.

Robnett, W.E. and P.R. Morey. 1974. Effect of ethephon on mesquite and huisache stem anatomy. Weed Sci. 22:280-284.

Salisbury F.B. and C.W. Ross. 1985. Plant physiology. 3rd ed. Wadsworth Publishing Co., Belmont. Calif. 15:204.

Shain, L. and W.E. Hillis. 1973. Ethylene production in Prunus radiata in response to Sire Amylostereum attack. Phytopathology 6: 1407-1409.

Schniewind. A.P., R.W. Cahn, and M.B. Bever. 1989. Concise encyclopedia of wood and wood-based materials. Pergamon Press. New York.

Wilson, B.F. ,T.J. Wodzicki. and R. Zahner. 1966. Differentiation of cambial derivatives: Proposed terminology. For. Sci. 12(4):438-440.

Weinbaum. S.A.. J.M. Labavitch. and Z. Weinbaum. 1979. The influence of ethylene treatment of immature fruit of prune (Prunus domestica L.) on the enzyme-mediated isolation of mesocarp cells and protoplasts. J. Amer. Soc. Hort. Sci. 104:278-280.

Yamamoto, F., G. Angeles, and T.T. Kozlowski. 1987. Effect of ethrel on stem anatomy of Ulmus americana seedlings. IAWA Bul. n.s. 8( 1 ):3-8.

Yamamoto, F. and T.T. Kozlowski. 1987a. Effect of ethrel on growth and stem anatomy of Pinus halapensis seedlings. IAWA Bul. n.s. 8(1 ):11-19.

Yamamoto, F. and T.T. Kozlowski. 1987b. Effects of flooding of soil on growth. stem anatomy and ethylene production of Thuja orientalis seedlings. IAWA Bul n.s. $8(1): 21-29$. 